\title{
Estimating Summer Squash Leaf Area Nondestructively
}

\section{D.S. NeSmith \\ D epartment of H orticulture, G eorgia Station, G riffin, GA 30223}

Crop leaf area estimates from nondestructive measurements of leaf length and width offer reliable, inexpensive alternatives to leaf area meters (Gamiely et al., 1991; Manivel and Weaver, 1974; Robbins and Pharr, 1987; Wiersma and Bailey, 1975). Additionally, these methods permit repeated sampling of the same plants over time, thus reducing some of the experimental variability associated with destructive sampling procedures. The objective of this research was to determine whether an existing cucumber (Cucumis sativus L.) leaf area model (Robbins and Pharr, 1987) would apply to summer squash (Cucurbita реро L.) since leaf morphology of these species is similar and, if not, to develop leaf area-estimating functions for summer squash

'Sunrise', 'Corona', 'Dixie', 'Lemondrop', 'Dark Star', and 'Senator' summer squash were sown in 3.5-liter pots containing commercial potting soil (Metro-Mix 300; W.R. Grace and Co., Cambridge, Mass.) and grown in a greenhouse. At the end of 4 weeks, at least 30 leaf lamina representing the range of leaf sizes present were sampled from each cultivar. Leaf lamina length (L) was measured after the method of Robbins and Pharr (1987), and leaf width (W) was measured at the widest point perpendicular to the lamina midrib. Actual leaf area (A) was determined for each lamina with a LICOR Model 3000 leaf area meter (LI-COR, Lincoln, Neb.).

Received for publication 26 Apr. 1991. Accepted for publication 15 Aug. 1991. A contribution of the Univ. of Georgia Agr. Expt. Sta., Georgia Station, Griffin. This research was supported by state and Hatch Act funds allocated to the Georgia Agr. Expt. Stas. The cost of publishing this paper was defrayed in part by the payment of page charges. Under postal regulations, this paper therefore must be hereby marked advertisement solely to indicate this fact.
Table 1. Models, coefficients of determination $\left(R^{2}\right)$, and error mean squares (MSE) of correlations between squash leaf area (A) and measurements of leaf length (L) and leaf width (W). Units are square centimeters for $A$, and centimeters for $\mathrm{L}$ and $\mathrm{W}$.

\begin{tabular}{lcc}
\hline \hline Model & $R^{2}$ & MSE \\
\hline$A=-2.5+0.77\left(\mathrm{~W}^{2}\right)$ & 0.976 & 693 \\
$\mathrm{~A}=-8.4+0.97(\mathrm{~L} \times \mathrm{W})$ & 0.983 & 495 \\
$\mathrm{~A}=102.3[\exp (0.07 \mathrm{~W})]-127.4$ & 0.976 & 695 \\
$\mathrm{~A}=24.5-3.9(\mathrm{~W})+0.89\left(\mathrm{~W}^{2}\right)$ & 0.977 & 669 \\
\hline
\end{tabular}

Statistical analyses revealed that the functions of Robbins and Pharr (1987) derived for cucumbers did not satisfactorily fit the squash data from the current experiment, indicating a different model was needed for summer squash. Several combinations of variables and regression equations were evaluated by comparing coefficients of determination $\left(R^{2}\right)$ and error mean squares (MSE); four combinations gave the best results (Table 1). No significant differences $(P$ $=0.05$ ) were found between cultivars. An equation using the product of $\mathrm{L}$ and $\mathrm{W}$ was the overall best equation in terms of $R^{2}$ and MSE. However, a model using $\mathrm{W}^{2}$ was similar in precision (Fig. 1). A model based on a single measurement offers the advantages of more efficient data collection and less complex calculations.

Summer squash leaf area cannot be estimated using a previously derived model for cucumber, but can be accurately and nondestructively estimated using leaf width. A single equation performed well for several commercial cultivars over a wide range of leaf sizes. Other squash cultivars will likely fit the functions derived in this experiment unless their leaf morphology differs greatly from those used here.

\section{Literature Cited}

Gamiely, S., W.M. Randle, H.A. Mills, and D.A. Smittle. 1991. A rapid and nondestructive method of estimating leaf area of onions. HortScience 26:206

Manivel, L. and R.J. Weaver. 1974. Biometric correlations between leaf area and leaf length measurements of 'Grenache' grape leaves. HortScience 9:27-28.

Robbins, S.N. and D.M. Pharr. 1987. Leaf area prediction models for cucumber from linear measurements. HortScience 22:1264-1266.

Wiersma, J.V. and T.B. Bailey. 1975. Estimation of leaf, trifoliate, and total leaf areas of soybeans. Agron. J. 67:26-30.

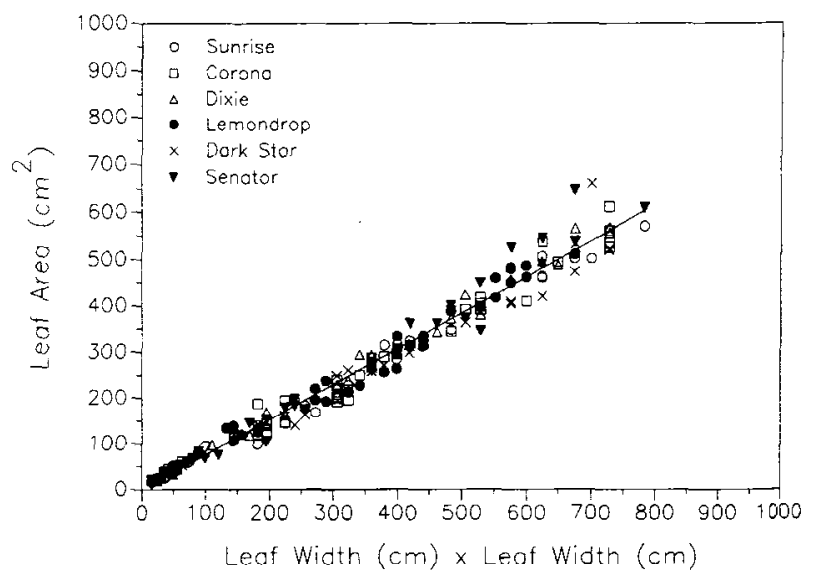

Fig. 1. Leaf area (A) of six squash cultivars as a function of leaf width (W) squared. The equation for the regression line is $\mathrm{A}=-2.5+0.77\left(\mathrm{~W}^{2}\right)$, from Table 1 . 